NBER WORKING PAPER SERIES

\title{
OFFSHORE JURISDICTIONS (INCLUDING CYPRUS), CORRUPTION MONEY LAUNDERING AND RUSSIAN ROUND-TRIP INVESTMENT
}

\author{
Svetlana Ledyaeva \\ Päivi Karhunen \\ John Whalley \\ Working Paper 19019 \\ http://www.nber.org/papers/w19019
}

\author{
NATIONAL BUREAU OF ECONOMIC RESEARCH \\ 1050 Massachusetts Avenue \\ Cambridge, MA 02138 \\ May 2013
}

The authors would like to thank Ronald Davies, Christian Gormsen, Pertti Haaparanta, Olena Havrylchyk, Konstantin Kholodilin, Michael Landesmann, Thierry Mayer, Svetlana Makarova, Miriam Manchin, Eugene Nivorozhkin, Aleksandra Riedl, Doris Ritzberger-Grünwald, Thierry Verdier, Julia Wörz and numerous seminar and conference participants for very valuable comments on earlier drafts of this paper. The first author thanks the staff of CEPII and OeNB for hospitality during the research visits in the Fall 2012 and Spring 2013, respectively. The second author acknowledges support from the Academy of Finland grant N 264948. The third author acknowledges support from the Ontario Research Fund (ORF). The paper has been previously circulating under the title "If foreign investment is not foreign: round-trip versus genuine foreign investment in Russia". The views expressed herein are those of the authors and do not necessarily reflect the views of the National Bureau of Economic Research.

NBER working papers are circulated for discussion and comment purposes. They have not been peerreviewed or been subject to the review by the NBER Board of Directors that accompanies official NBER publications.

(C) 2013 by Svetlana Ledyaeva, Päivi Karhunen, and John Whalley. All rights reserved. Short sections of text, not to exceed two paragraphs, may be quoted without explicit permission provided that full credit, including $(\mathrm{C}$ notice, is given to the source. 
Offshore jurisdictions (including Cyprus), corruption money laundering and Russian round-trip investment

Svetlana Ledyaeva, Päivi Karhunen, and John Whalley

NBER Working Paper No. 19019

May 2013

JEL No. F21,F23

\section{ABSTRACT}

In this paper we analyze the link between corruption money laundering and round-trip investment via offshore jurisdictions utilizing Russian firm-level data. In particular we empirically explore location strategies of round-trip investors (namely, from Cyprus and British Virgin Islands) across Russia and compare them with the benchmark group of genuine foreign investors in Russia. We further study the determinants of the fraction of round-trip investment in total foreign investment in Russian regions. We find that round-trip investors tend to locate in more corrupt Russian regions than their genuine foreign counterparts and the fraction of round-trip investment is also significantly higher in corrupt regions. Taking into account that a large fraction of round-trip investment in Russia is concentrated in real estate and financial sectors, our results point to the conclusion that there is a strong link between round-trip investment and corruption money laundering.

Svetlana Ledyaeva

Aalto University

School of Economics

P.O. Box 21240

FI-00076 AALTO

Finland

Svetlana.Ledyaeva@aalto.fi

Päivi Karhunen

Aalto University

School of Economics

P.O. Box 21240

FI-00076 AALTO

Finland

paivi.karhunen@aalto.fi
John Whalley

Department of Economics

Social Science Centre

University of Western Ontario

London, ON N6A 5C2

CANADA

and NBER

jwhalley@uwo.ca 


\section{INTRODUCTION}

Corruption has obvious connection with money laundering. As it is argued in Financial Action Task Force (FATF) report 2011 "the stolen assets of a corrupt public official are useless unless they are placed, layered, and integrated into the global financial network in a manner that does not raise suspicion”. It is further argued in the report that corrupt public officials would seek to move financial proceeds of corruption outside of their home jurisdiction. An examination of the corruption case studies revealed that in nearly every case foreign bank accounts were being used in part of the scheme. The proceeds of corruption may be laundered in jurisdictions which have not enacted strict anti-money laundering measures and in countries which uphold very strict bank secretary laws or regulations (Rossidou-Papakyriacou, 1999). Offshore financial centers are widely recognized as such jurisdictions.

Corruption money laundering in offshore financial centers is further connected with another largely unexplored phenomenon in the world economy - round-trip investment, i.e. the transfer of funds abroad in order to bring some or all of the investment back to home country as foreign investment. E.g. as has been recently noted in press: "Most foreign investment in BRICs isn`t foreign at all - it`s tycoons using tax havens”1 . Each BRIC country has its own offshore jurisdiction largely used for capital round-tripping. For China it is the tiny "bolthole” of the British Virgin Islands, for India - Mauritius, for Russia - Cyprus and for Brazil - the Netherlands.

The consequences of such round-trip investment for national economies can be quite dramatic. E.g. in China the bulk of these round-trip investments is from shell companies, which are registered by corrupt Chinese officials in offshore jurisdictions. Since round-trip investment mainly flows to real estate speculation, it distorts China`s entire economic structure².

Though there are numerous journalist articles and opinions of leading economic analysts and politicians on the link between corruption money laundering and round-trip investment via offshore jurisdictions, this issue is practically unexplored in academic literature. In this paper we empirically analyze the link between corruption money laundering and round-trip investment utilizing Russian firm-level data.

\footnotetext{
${ }^{1}$ http://qz.com/66944/the-brics-biggest-investment-sources-are-tax-havens-which-mostly-shows-the-rich-stealingfrom-the-poor/

${ }^{2}$ http://www.setyoufreenews.com/2013/02/28/fake-foreign-investment-pushes-chinese-economy-to-brink/
} 
A distinctive feature of foreign investment patterns for Russia is the correlation of inward and outward investment flows between Russia and key offshore financial centers (OFCs) such as Cyprus and British Virgin Islands (BVI) ${ }^{3}$. According to Russian statistics, the key offshore destinations of Russian registered capital outflows, Cyprus and BVI, are persistently among the major source countries of inward foreign investment into Russia. And as in accordance to Perez et al. (2012) study over 20\% FDI to money laundering countries from a selection of transition countries were made to facilitate illicit money flows, it is plausible to suggest that there should be a strong relationship between corruption money laundering and round-trip investment in Russia.

In empirical test we utilize a sample of firms with foreign ownership that have been registered in Russia during the period 1997-2011. The data comes from ROSSTAT - the Russian State Statistical Agency - the most reliable data source of economic statistics on Russia.

In this study we consider two groups of foreign investors. The first one is represented by foreign investors from Cyprus and British Virgin Islands, i.e. the OFCs which are very popular with round-tripping activities of Russians. The second, benchmark group for comparison, consists of genuine foreign investors and includes investors from such countries as Germany, Sweden, Finland and USA among the others.

First, using knowledge-capital model of the multinational enterprise of Carr et al. (2001), we provide a formal (empirical) analysis of the phenomenon of round-trip investment in the Russian economy. In particular we find very strong evidence that the amounts of foreign investment into Russia from Cyprus and BVI cannot be explained within traditional international investment theory which confirms round-trip investment hypothesis.

Second, we empirically study the differences in location strategies between round-trip and genuine foreign investors across Russian regions. Here we find rather convincing evidence that round-trip investors tend to invest into Russian regions with higher levels of resource potential and corruption. The explanation for the result for resource potential is two-fold. On the one hand it points to the restrictions for genuine foreign investment in Russian resource sector. On the other hand it reflects the circulation of money earned

\footnotetext{
3 According to the most popular and recognized definition, OFC is a centre which provides some or all of the following services: low or zero taxation; moderate or light financial regulation; banking secrecy and anonymity. Though in general both Cyprus and BVI satisfy this definition, we should mention that Cyprus's future as an offshore financial centre has been in serious jeopardy when the island adopted full EU membership in 2004. However, due to cleverly adjusted taxation policies in the interests of corporations and foreign retirees, Cyprus remained an offshore tax haven of some note. Source: http://www.shelteroffshore.com/index.php/offshore/more/positive-developments-cyprus-offshore-financial-centre-10519
} 
by Russians in exploitation and export of natural resources via OFCs. The reasons of such circulation might include tax avoidance (on profits from export of natural resources).

The result for corruption holds both in manufacturing and combined real estate and financial activities sectors. However, we argue that the explanations can be different. On the one hand, for manufacturing sector the preference of round-trip investors to locate in more corrupt Russian regions might reflect their better abilities to deal with corrupt Russian regional authorities. On the other hand, the result that round-trip investors tend to establish firms in real estate and financial sectors in more corrupt regions, in our view, just reflects the corruption money laundering via round-trip investment hypothesis as these sectors are largely associated with corruption.

Third, we empirically analyze the factors which determine the fraction of round-trip investment in total foreign investment across Russian regions. Here we find very strong evidence that the share of roundtrip investment is considerably higher in more corrupt Russian regions. This result holds for all main industrial sectors and gives further support for corruption money laundering hypothesis.

In general our empirical results give a strong support that round-trip investment is an important channel of corruption money laundering in Russia. This suggests that offshore jurisdictions indirectly facilitate corruption in the world economy. The existence of such jurisdictions makes the process of laundering of money earned in dishonest activities (corruption or criminal) considerably easier.

The paper is structured as follows. Section 2 and 3 describe the data and empirical methodology, respectively. Section 4 presents the empirical results. Finally, section 5 discusses the results and concludes.

\section{DATA DESCRIPTION}

Our empirical analysis makes use of Rosstat (Russian State Statistical Agency) dataset, which provides information on the location choice of 20,165 firms with foreign capital registered in Russia in the period between 1997 and 2011 and provided financial reports to Rosstat in 2011. This dataset includes information on firms of two ownership types: full ownership of foreign entities and joint ventures of foreign owners (foreign entities and foreign citizens) with Russian private owners (Russian entities and citizens). For each firm, we use data that Rosstat records on: 
- Industry information, including the six-digit OKVED code (Russian equivalent to SIC sixdigit codes) of the primary industry in which a firm operates;

- Ownership structure, including information about firms`owners (country of origin, company`s name, share in capital) and ownership status;

- Location information, including a region;

- Year of registration;

- Charter capital size at the moment of registration;

- Annual gross revenues in the period of 1998-2011 (when available).

From this dataset we extract two types of firms. First group consists of firms which foreign ownership is represented by offshore owners (i.e. OFCs). In this study the offshore owners are represented by investors from Cyprus and BVI. We assume that this group represents round-trip investors. The second group consists of firms for which foreign ownership is represented by genuine foreign owners. The genuine foreign (non-offshore) owners are more diversified: main investors are Germany, USA, Finland, China, Turkey, France and Sweden. We should note here that we do not include firms established by investors from Netherlands, Luxemburg, Liechtenstein, Switzerland, Austria and Great Britain in either of these two groups. On the one hand, these countries can be considered as offshore countries popular with Russian flight capital. On the other hand, a large portion of foreign investment from these countries might have "real foreign" origin.

Our final sample consists of 15, 174 firms (5,712 (38 \%) firms are established by investors from Cyprus; 1,688 (11 \%) - by investors from BVI and 7,774 (51\%) - by genuine foreign investors). More than 70\% of firms are concentrated in three sectors: trade and repair (28,5\%), real estate (29\%) and manufacturing industries (12, 7\%). On figure 1 we present the distributions of firms in these sectors (plus financial sector due to its popularity with round-trip investors) by origin of foreign investor. 
Figure 1 The structure (in \%) of firms (by number) by origin of foreign investor within sectors of economy (as cumulative in the period of 1997-2011)

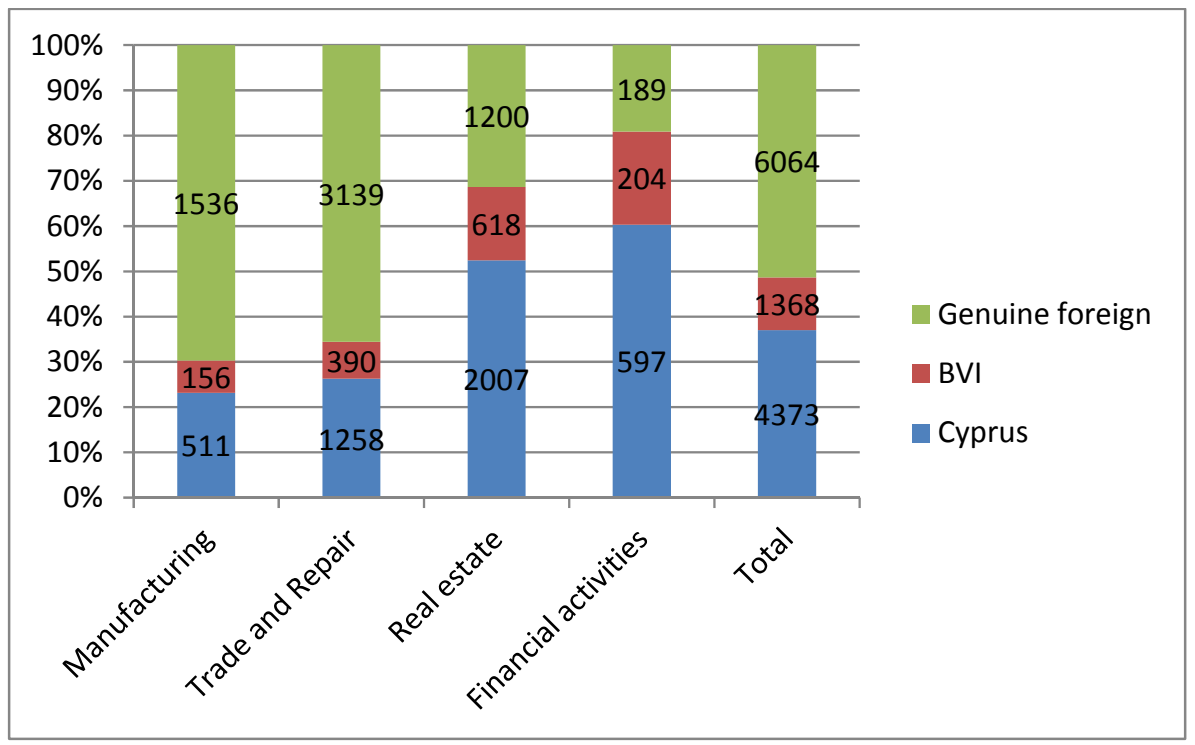

Note: The numbers on the chart denote the number of established firms by a certain type of investor in a certain industry. Source: Rosstat and authors' calculations.

As we can see around $70 \%$ of firms in manufacturing industries and around $67 \%$ - in trade and repair sector - are established by genuine foreign investors. On the other hand around 70\% of firms in real estate sector and around $80 \%$ of firms in financial sector are established by round-trip investors. This evidence already reflects a corruption nature of round-trip investment as real estate and financial sectors are commonly associated with corruption money laundering.

In manufacturing sector, around 18\% of Cypriot firms are established in manufacturing of food and beverages, around $11 \%$ - in chemical production and around 9\% - in publishing and polygraphic activities. Around 22\% of BVI firms are established in manufacturing of food and beverages, around 16\% - in publishing and polygraphic activities and around 9\% - in wood processing and manufacturing goods from wood, except furniture. Finally around $15 \%$ of firms established by genuine foreign investors are in manufacturing of machine and equipment, around $11 \%$ - in manufacturing of food and beverages and around $9 \%$ - in manufacturing of non-metallic mineral goods. 
On figure 2 we present the structure of established firms by average annual gross revenues according to the Russian classification of the companies' size by annual gross revenues (Dolmatova, 2010).

Figure 2 Distribution of firms (established in the period of 1997-2011) by size of average annual gross revenues (AGR) in the period of 1998-2011

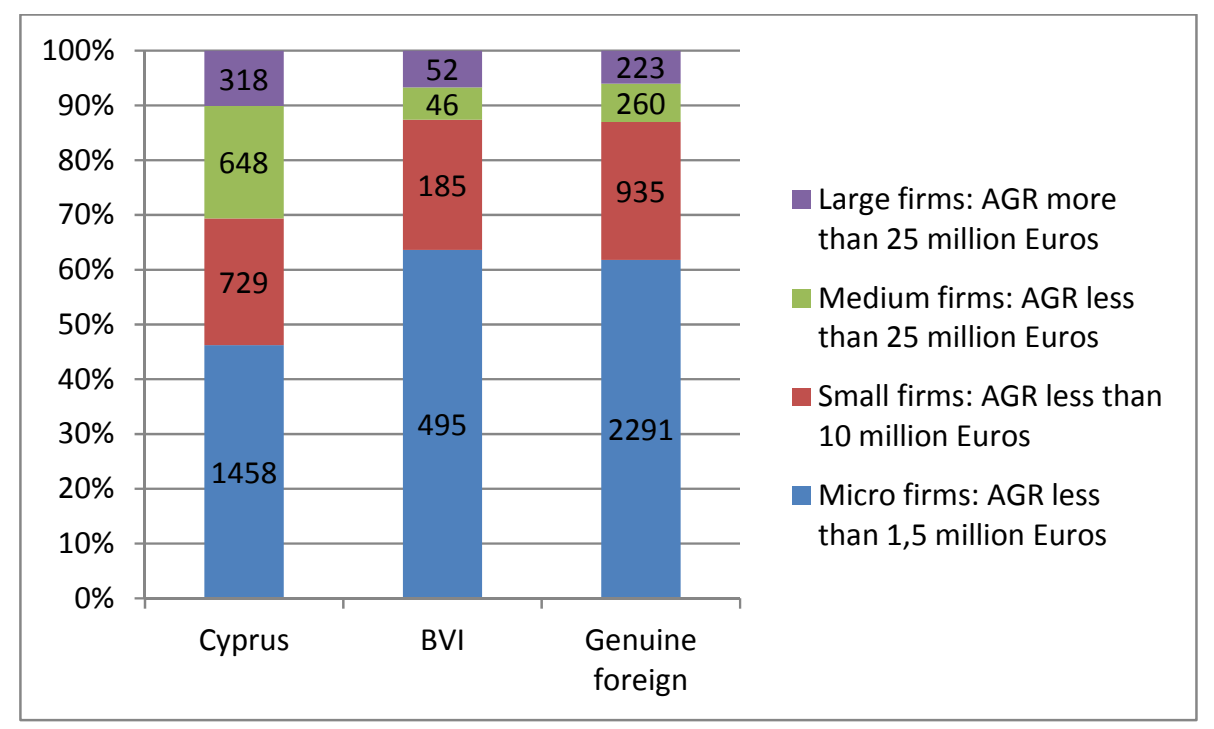

Note: The numbers on the chart denote the number of established firms by a certain type of investor of a certain size Source: Rosstat and authors calculations

Micro and small firms strongly dominate in our sample. This pattern is slightly stronger for firms established by genuine foreign investors. There can be several explanations for this fact. First, small firms are more flexible than larger ones to changing environment in an unstable transition economy. Second, establishing small firms requires fewer permissions, bureaucracy work, etc. than for larger firms which might be also important for investors in such a corrupt and bureaucratic country like Russia. The largest firms are established in trade sector followed by manufacturing and financial sectors. The relative patterns do not differ much between the groups of investors except that round-trip investors establish significantly larger firms in the financial sector compared to genuine foreign investors. 
Both round-trip and genuine foreign investments are highly concentrated in three Russian regions, namely, Moscow city, Saint-Petersburg city and Moscow region. 65\% of firms established by investors from Cyprus are registered in Moscow city, 13\% - in Moscow region and 7\% - in Saint-Petersburg. The corresponding shares for BVI are 76, 10 and 7\% and for genuine foreign investors - 56, 12 and 12\%. The dominance of established firms in Moscow city is partly explained by the fact that companies have their head offices in Moscow but real production activities are located in regions. Unfortunately, from our data we cannot separate those firms that conduct real business in other regions but locate in Moscow.

On figure 3 we plot the number of firms established by round-trip investors (Cyprus and BVI) against the number of firms established by genuine foreign investors across Russian regions. We exclude Moscow, Moscow region and St. Petersburg because of scale problem.

Figure 3 Round-trip (Cyprus and BVI) vs. genuine foreign investors across Russian regions (by number of established firms as cumulative in the period of 1997-2011)

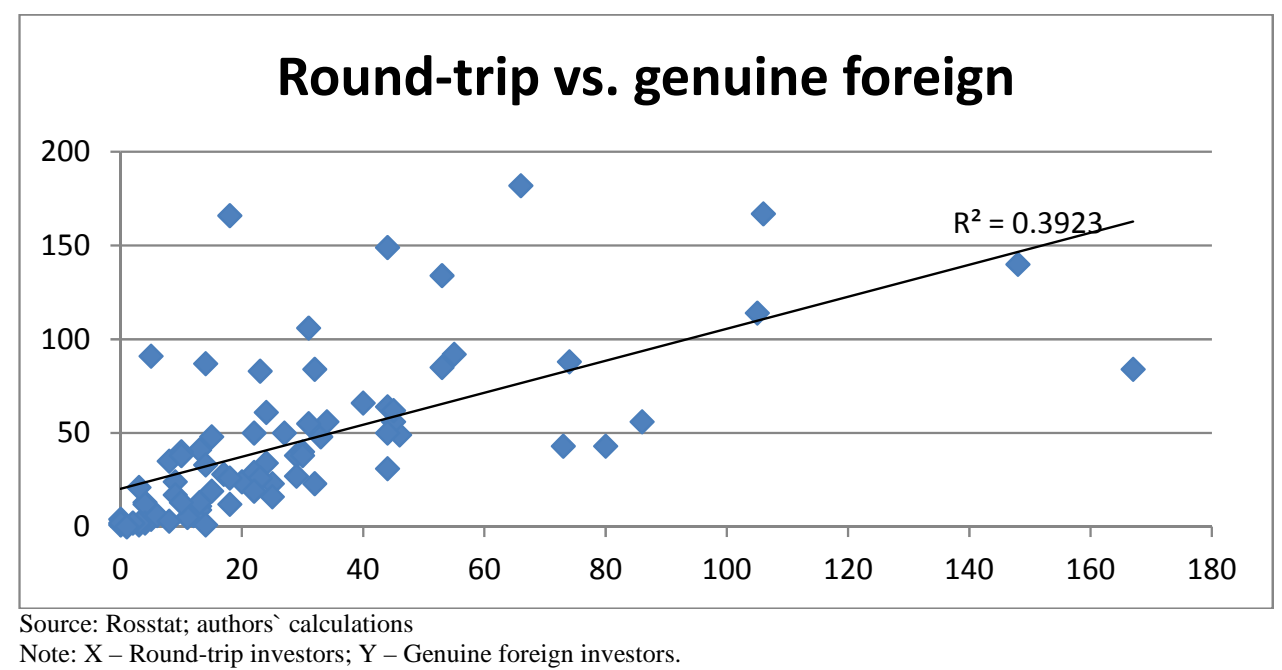

From the figure we can see that though there is positive relationship in distribution of the two types of firms across Russian regions, it is far from being perfectly identical (i.e. 45 degree line). This evidence indicates that there are substantial differences in location strategies between round-trip and genuine foreign investors across Russia. 


\section{EMPIRICAL STRATEGIES}

\subsection{Knowledge-capital model of the multinational enterprise frameworks}

First, we estimate the knowledge-capital model of the multinational enterprise suggested by Carr et al. (2001) with offshore dummies (adapted to our case of one host country (Russia) and multiple home countries). We suggest that if offshore dummies are statistically significant and positive, then foreign investments from OFCs exceeds the amounts predicted by traditional economic theory which gives support for round-trip investment hypothesis (similar approach has been used by Rose and Spiegel (2007)). The updated model is as follows:

$$
\begin{aligned}
& \text { RSALES }_{j, t}=\beta_{0}+\beta_{1} \text { SUMGDP }_{j R U S, t}+\beta_{2} \text { GDPDIFFSQ }_{j R U S, t}+\beta_{3} \text { SKDIFF }_{j R U S, t}+ \\
& \beta_{4} \text { GDPDIFF }_{j R U S, t} * \text { SKDIFF F }_{j R U S, t}+\beta_{5} \text { INVCRUS }_{t}+\beta_{6} \text { TCRUS }_{t}+\beta_{7} \text { TCRUS }_{t} * \text { SKDIFFSQ }_{j R U S, t} \\
& +\beta_{8} \text { TCJ }_{j, t}+\beta_{9} \text { DISTANCE }_{j R U S}+\beta_{10} \text { OFFD }+\beta_{11} \text { OFF } 2+u_{j}+e_{j t}
\end{aligned}
$$

where $R S A L E S_{j, t}$ is the sum of real annual gross revenues of firms established by foreign investors from a parent country $\mathrm{j}$ in a year $\mathrm{t}(2002, \ldots, 2011) . S U M G D P_{j R U S, t}$ is the sum of GDP of a parent country $\mathrm{j}$ and Russia in a year t. GDPDIFF ${ }_{j R U S, t}$ is the difference between GDP of a parent country j and GDP of Russia in a year t.GDPDIFFSQ $Q_{j R U S, t}$ is the squared $G D P D I F F_{j R U S, t}$. Annual gross revenues values which are originally in Russian roubles and GDP values of all countries have been converted into 2005 US dollars using an exchange rate adjusted local wholesale price index with exchange rates and price indices taken from the International Financial Statistics (IFS) of the International Monetary Fund.

The variable $S K D I F F_{j R U S, t}$ is a measure of skilled labour abundance in a country j relative to Russia in a year t. SKDIFFSQ ${ }_{j R U S, t}$ is the squared $S K D I F F_{j R U S, t}$. Skilled labour abundance is measured by Gross Enrolment Ration (tertiary (ISCED 5 and 6)) of the World Bank database. 
INVCRUS $_{t}$ and TCRUS $S_{t}$ respectively measure costs of investing in, and exporting to, Russia in a year t. $T C J_{j, t}$ measures trade costs in exporting to parent country $\mathrm{j}$ in a year t. Investment costs in Russia are measured by Investment dimension of the Index of Economic Freedom of the Heritage Foundation. Trade costs in Russia and parent countries are measured by taxes on international trade (\% of revenues) of the World Bank database. Taxes on international trade include import duties, export duties, profits of export or import monopolies, exchange profits, and exchange taxes.

Finally, to the baseline model we add two dummy variables. The first one, OFFD, equals to one for Cyprus and BVI and zero otherwise. The second one, OFF2, equals to one for Austria, Liechtenstein, Luxemburg, Netherlands and Great Britain and zero otherwise. The latter variable counts for the countries which can be partly considered as popular with round-tripping activities of Russian investors.

We estimate the equation (1) using panel data model with random effects. We do not use fixed effects because our main variables of interest - two offshore dummies - are time-invariant and thus subsumed by regional fixed effects.

\subsection{Location model framework: three dimensional panel data framework}

The aim of our empirical analysis within location model framework is to determine if and to what extent the role of regional factors in the location decisions of foreign investors across Russian regions differs between round-trip and genuine foreign investors. More precisely, we estimate the following equation:

$$
\begin{aligned}
& y_{i t j}=\beta_{0}+\beta_{1} \text { RES }_{i, t-1}+\beta_{2} \text { Corr }_{i}+\beta_{3} \text { Port }_{i}+\beta_{4} \text { MSize }_{i, t-1}+\beta_{5} \text { Mpot }_{i, t-1}+\beta_{6} \text { RIR }_{i, t-1} \\
& +\beta_{7} \text { EDU }_{i}+\beta_{8} \text { RIP }_{i, t-1}+\beta_{9} \text { Roads }_{i, t-1}+\beta_{10} \text { OFFd }_{j}+\beta_{11} \text { RES }_{i, t-1} * \text { OFFd }_{j}+ \\
& \beta_{12} \text { Corr }_{i} * \text { OFFd }_{j}+\beta_{13} \text { Port }_{i} * \text { OFFd }_{j}+\beta_{14} \text { Msize }_{i, t-1} * \text { OFFd }_{j}+\beta_{15} \text { Mpot }_{i, t-1} * \text { OFFd }_{j} \\
& +\beta_{16} \text { RIR }_{i, t-1} * \text { OFFd }_{j}+\beta_{17} \text { EDU }_{i} * \text { OFFd }_{j}+\beta_{18} \text { RIP }_{i, t-1} * \text { OFFd }_{j}+ \\
& \beta_{19} \text { Roads }_{i, t-1} * \text { OFFd }_{j}+\sum_{t} \delta_{t} \text { Year_Dummies }+u_{i}+e_{i t}
\end{aligned}
$$

where $y_{i j}$ is the number of established firms in a particular Russian region, $\mathrm{i}(\mathrm{i}=1, \ldots, 76)$, in a given year, $\mathrm{t}$ $(t=1997, \ldots, 2010)$ by a $j(1,2)$ type of investor (round-trip and genuine foreign). Hence, we deal with threedimensional panel data. The explanatory variables are described below in subsection 4.2.1; the time-varying 
control variables are lagged by one year. The use of lagged explanatory variables helps to solve possible endogeneity problems and further relate to a simple hypothesis for the foreign investor`s decision-making process: foreign investors are assumed to make an investment decision for a given year by referring to the observable variables of the previous year (see, e.g., Ledyaeva, 2009).

We also include an offshore dummy OFFd which equals to one for round-trip investors (Cyprus and BVI in this study) and zero for their genuine foreign counterparts. We further include the interaction terms between OFFd and all the explanatory variables in order to estimate the differences in the role of regional factors in location decisions between round-trip and genuine foreign investors.

Finally, we include time (year) dummies. $u_{i}$ is unobserved regional heterogeneity and $e_{i t}$ is idiosyncratic error.

\subsubsection{Explanatory variables}

$R E S$, the natural resources` potential variable, is measured using an online Expert $R A$ journal ${ }^{4}$ ranking $^{5}$ for a particular region, i, in a given year, t-1 (from 1 to 89/83: 1 corresponds to the highest potential and 89/83 corresponds to the lowest potential).

Corruption CORR in a Russian region $\mathrm{i}$ is measured using the corruption dimension provided by the Moscow Carnegie Center`s Index of Democracy for the period 2000-2004 (as average). It is measured on a 5-point scale, where 1 indicates the highest level of corruption and 5 indicates the lowest. This indicator refers mainly to state corruption in a broader sense, that is, the interconnections between political and business elites and their interventions in the political decision-making process. To our knowledge, this is the only indicator of corruption that is available for all of the Russian regions. ${ }^{6}$

The variable Port reflects the presence of a seaport in a particular Russian region (a dummy variable that is equal to one if there is at least one sea port in a region and zero otherwise).

MSize, the market size variable, is the first principal component of three variables (gross regional product, total population, and population density) for a particular region, i (i=1,..,76), in a given year, t-1

\footnotetext{
${ }^{4}$ http://www.raexpert.ru/ - official webpage of Expert Rating Agency (RA), the most respected rating agency in the CIS and Eastern Europe.

${ }^{5}$ This indicator reflects the average weighted availability of balanced stocks of principal natural resources in the Russian regions.

${ }^{6}$ The only alternative is the index of corruption of Transparency International and Fund INDEM (2002). However, the index was only computed for 40 Russian regions, which would pose serious limitation on our study.
} 
( $t=1996-2007)$. This indicator for the market size in Russian regions was introduced previously in a study by Iwasaki and Suganuma (2005). The proportion of variance of the first component can reach $80 \%$, and furthermore, its eigenvector and component loading show that this variable is suitable as a general index of market size.

We also include a surrounding-market potential variable, MPot (see Blonigen et al., 2007). For a region, $\mathrm{i}$, it is defined as the sum of the market sizes (measured using the MSize variable) of the surrounding regions within a distance of $500 \mathrm{~km}$ (between the capital of a particular Russian region and the capital of a neighbouring (but not necessarily bordering) region). This distance threshold between neighbouring regions has been chosen based on the "trial-and-error" method. This variable is also lagged by one year.

Regional investment risk, RIR, is an online Expert $R A$ journal ranking ${ }^{7}$ ranging from 1 to 89/83 for a particular Russian region, i, in a given year, t-1 (1 is assigned to a region with the smallest risk in Russia, and $89 / 83$ is assigned to a region with the largest risk).

The next variable is the educational background of population in a Russian region, EDU. It is measured using a natural logarithm of the share of population with at least a medium level of professional education compared to the share of population with no professional education in a particular Russian region in the year 2002 (the data comes from the Rosstat Population Census for 2002).

Regional institutional potential, RIP, is an online Expert $R A$ journal ranking ${ }^{8}$ ranging from 1 to 89/83 for a particular Russian region, i, in a given year, t-1 (1 is assigned to a region with the highest potential in Russia, and 89/83 is assigned to a region with the lowest potential).

Finally, the variable Roads reflects the regional development of railways and highways and is measured by the average density of railways and highways in a particular region, i, in a given year, t-1.

\subsubsection{Econometric methodology}

The dependent variable in the location model is a count variable, and it takes on only non-negative integer values. While a Poisson regression is appropriate for modeling the count data, our data is significantly overdispersed, and hence, it violates a basic assumption of the Poisson model (Hausman, Hall,

\footnotetext{
${ }^{7}$ This is a qualitative indicator that simultaneously reflects political, economic, social, criminal, financial, ecological, and legislative risks for investment activities in the Russian regions.

${ }^{8}$ This indicator reflects the level of development of principal market institutions in the Russian regions.
} 
and Griliches, 1984). Consequently, as recommended in the literature, we use negative binomial (NB) regression to model the count data (Hausman et al., 1984). Since our data has a panel structure, we estimate equation (1) using a negative binomial panel model. The negative binomial panel estimator accommodates the explicit control of persistent, individual, unobserved effects through either fixed or random effects. We employ regional random effects to control for unobserved regional differences. We do not use fixed effects for two reasons. First, several our explanatory variables are time-invariant and thus subsumed by regional fixed effects. Second, the maximum likelihood estimation - implemented using STATA - failed to converge with the inclusion of region-specific dummies. The reason for this is that the Newton-Raphson method used to estimate the likelihood functions in STATA is sensitive to the number of variables (see also Hedge and Hicks, 2008). We also include year dummies to control for unobserved systematic period effects.

The distribution of our dependent variable also contains a large number of zeros - nearly $31 \%$ for the whole sample and up to $60 \%$ for subsamples. This suggests that our data may contain excess zeros relative to the data generated using a standard negative binomial process. Failure to account for these extra zeros may result in biased parameter estimates (Lambert, 1992). Accordingly, we also estimated equation (2) using a zero-inflated negative binomial (ZINB) model. Because we could not find a panel data version of the ZINB model in the existing econometrics literature (see also Basu et al., 2011, p. 167), we employed a standard ZINB estimator and computed standard errors that are robust for both clustering within regions and heteroscedasticity. We should also mention that the ZINB model maximum likelihood estimation, implemented in STATA, similar to the ordinary negative binomial model mentioned in the previous paragraph, failed to converge when region-specific dummies (fixed effects) were included due to a collinearity problem and an excessive number of explanatory variables. Hence, when using the ZINB model, we estimated the reduced form of equation (1) by excluding $u_{i}$, unobserved regional heterogeneity.

The ZINB model assumes that the population is characterized by two regimes: One where members are "not at risk," and thus always have zero counts, and another where members are "at risk," and thus have either zero or positive counts (Greene, 2000). The likelihood of being in either regime is estimated using logit specification, while the counts in the second regime are estimated using a negative binomial specification. Potentially, the same set of explanatory variables can be used in each stage of the process 
(Basile, 2004). After different attempts, however, a subset of variables was selected to specify the splitting function: Corr, Msize, RIP and Roads.

\subsection{Fractional dependent variable model framework}

At this stage we analyze the regional factors of the fraction of round-trip investment in total investment across Russian regions. In particular we estimate the following equation:

$$
\begin{aligned}
& F_{R T}=\beta_{0}+\beta_{1} R E S_{i t}+\beta_{2} \text { Corr }_{i}+\beta_{3} \text { Port }_{i}+\beta_{4} \text { Msize }_{i t}+\beta_{5} \text { Mpot }_{i t}+ \\
& \beta_{6} R R_{i t}+\beta_{7} \text { EDU }_{i}+\beta_{8} R I P_{i t}+\beta_{9} \text { Roads }_{i t}+\text { Year_Dummies }+e_{i t}
\end{aligned}
$$

where $F R T_{i t}$ is a fraction of the sum of gross annual revenues earned by firms with foreign ownership of investors from Cyprus and BVI in the total sum of gross annual revenues earned by all firms with foreign ownership (i.e. the sum of two considered groups in our study) in a Russian region i $(1, \ldots, 76)$ in a year $t$ $(2002, \ldots, 2011)$. At this stage we consider only firms established in the period of 1997-2001; i.e. the number of firms is fixed for the analyzed period (2002-2011). The explanatory variables are the same as in location model.

We utilize a fractional logit pooled data model to estimate the equation (3) as recommended in the relevant literature (for details see Papke and Wooldridge (1996; 2008)).

\section{EMPIRICAL RESULTS}

\subsection{Knowledge-capital model of the multinational enterprise: estimation results}

In table 1 we present estimation results of knowledge-capital model for our data (whole sample and subsamples of main industrial sectors) using panel data model with random effects. Prior to estimation all of the variables except dummies have been standardized. 
Table 1 Knowledge-capital model of multinational enterprise: panel data model with random effects Dependent variable is the sum of annual gross revenues in a year $t(2002, \ldots, 2011)$ of firms with foreign ownership of investors from a parent country j.

\begin{tabular}{|c|c|c|c|c|c|c|c|c|}
\hline \multirow[t]{2}{*}{$\begin{array}{l}\text { Variable } \\
\end{array}$} & \multicolumn{2}{|l|}{ All firms } & \multicolumn{2}{|c|}{ Manufacturing } & \multicolumn{2}{|c|}{ Trade and repair } & \multicolumn{2}{|c|}{$\begin{array}{llll}\text { Financial and real estate } \\
\text { sectors } & & & \\
\end{array}$} \\
\hline & (1) & (2) & (1) & (2) & (1) & (2) & (1) & (2) \\
\hline Intercept & $.08(0.2)$ & $-.17(0.1)^{*}$ & $.2(0.33)$ & $-.04(0.26)$ & $.04(0.2)$ & $-.26(0.08)^{* * *}$ & $.53(0.26)^{* *}$ & $.34(0.2)^{* *}$ \\
\hline SUMGDP & $.03(0.05)$ & $.08(0.01)^{* * *}$ & $.01(0.12)$ & $.1(0.03)^{* * *}$ & $.01(0.04)$ & $.12(0.01)^{* * *}$ & $-.01(0.1)$ & $.004(0.02)$ \\
\hline GDPDIFFSQ & $-.12(0.03)^{* * *}$ & $-.07(0.02)^{* * *}$ & $-.1(0.1)$ & $-.1(0.05)^{* *}$ & $-.14(0.03)^{* * * *}$ & $-.12(0.02)^{* * *}$ & $-.01(0.08)$ & $.002(0.03)$ \\
\hline SKDIFF & $.002(0.02)$ & $.003(0.01)$ & $-.06(0.06)$ & $.02(0.02)$ & $-.01(0.02)$ & $.001(0.01)$ & $-.02(0.04)$ & $-.0002(0.01)$ \\
\hline GDPDIFF*SKDIFF & .02(0.02) & .02(0.01) & .02(0.05) & $.05(0.04)$ & $.03(0.01)^{* *}$ & $.03(0.01)^{* * *}$ & $-.01(0.03)$ & $.001(0.02)$ \\
\hline INVCRUS & $-.01(0.15)$ & $.04(0.13)$ & $-.32(0.43)$ & $-.26(0.38)$ & $.06(0.12)$ & $.2(0.11)^{*}$ & $-.6880 .32)^{* *}$ & $-.7(0.3)^{* * *}$ \\
\hline TCRUS & $.02(0.27)$ & $.1(0.24)$ & $-.5(0.79)$ & $-.43(0.71)$ & $.14(0.22)$ & $.38(0.21)^{*}$ & $-1.24(0.58)^{* *}$ & $-1.2(0.5)^{* *}$ \\
\hline TCRUS*SKDIFFSQ & $-.0180 .01)$ & $-.02(0.01)^{* *}$ & $-.03(0.03)$ & $-.01(0.02)$ & $-.01(0.01)$ & $-.02(0.01)^{* *}$ & $-.004(0.024)$ & $-.002(0.01)$ \\
\hline TCI & $.02(0.01)^{* *}$ & $.02(0.004)^{* * *}$ & $.04(0.03)$ & $.02(0.01)^{*}$ & $.02(0.01)^{* * *}$ & $.02(0.01)^{* * *}$ & $.002(0.02)$ & $.001(0.01)$ \\
\hline Distance & $-.06(0.17)$ & $-.01(0.003)^{* * * *}$ & $-.05(0.14)$ & $-.02(0.01)^{* *}$ & $-.04(0.17)$ & $-.01(0.004)^{*}$ & $-.06(0.15)$ & $-.001(0.01)$ \\
\hline OFFD & & $10.1(0.03)^{* * *}$ & & $8.5(0.09)^{* * *}$ & & $10.1(0.04)^{* * *}$ & & $8.8(0.06)^{* * *}$ \\
\hline OFF2 & & $.13(0.01)^{* * * *}$ & & $.57(0.04)^{* * *}$ & & $.06(0.02)^{* * *}$ & & $.07(0.03) * * *$ \\
\hline Time dummies & Yes & Yes & Yes & Yes & Yes & Yes & Yes & Yes \\
\hline N. obs. & 308 & 308 & 308 & 308 & 308 & 308 & 308 & 308 \\
\hline
\end{tabular}

Note: 1$) *$ if $\mathrm{p}<0.10, * *$ if $\mathrm{p}<0.05 ; * * *$ if $\mathrm{p}<0.01 ; 2$ ) standard errors in parentheses.

As we can see, both offshore dummies are highly statistically significant and have positive signs in the whole sample and all the industrial subsamples which give strong support that these countries invest significantly more into Russia than can be explained within the knowledge-capital model. Furthermore, offshore dummy for Cyprus and BVI is significantly larger by magnitude than the offshore dummy for Austria, Liechtenstein, Luxemburg, Netherlands and Great Britain which indicates the higher importance of the former countries as the centers for round-tripping activities of Russian investors. It can be also noted that knowledge-capital model performs much better when the offshore dummies are included which further points to the importance of analyzing the phenomenon of round-trip investment in the context of Russian economy. 


\subsection{Location choice of round-trip and genuine foreign investors across Russian regions}

\subsubsection{Baseline specification}

In table 2 we present estimation results of the random effects negative binomial (RENB) panel data model and zero-inflated negative binomial (ZINB) model for the whole sample. We also present estimation results of equation (2) separately for the subsamples of round-trip and genuine foreign investors (then offshore dummy and its interactions vanish) and for pooled data when the offshore dummy and its interaction terms with explanatory variables are not included. Basic descriptive statistics and correlation matrix are presented in Appendix 1. Here and after we do not report the results for the inflation stage of ZINB estimations for space reasons and make them available upon request. 
Table 2 Location model: RENB and ZINB models baseline results

Dependent variable is the number of firms established in a Russian region $n(1, \ldots, 76)$ in a year $t(1997, \ldots, 2010)$ by an investor $j$

(1,2: round-trip and genuine foreign)

\begin{tabular}{|c|c|c|c|c|c|c|c|c|}
\hline Variable & RENB & & & & ZINB & & & \\
\hline & Round-trip & $\begin{array}{l}\text { Genuine } \\
\text { foreign }\end{array}$ & Pooled & $\begin{array}{l}\text { With } \\
\text { interactions }\end{array}$ & Round-trip & $\begin{array}{l}\text { Genuine } \\
\text { foreign }\end{array}$ & Pooled & $\begin{array}{l}\text { With } \\
\text { interactions }\end{array}$ \\
\hline Intercept & $1.96(0.46)^{* * *}$ & $1.7(0.5)^{* * *}$ & $1.25(0.34)^{* * *}$ & $.81(0.4)^{* *}$ & $-.41(0.24)^{*}$ & $-.51(0.21)^{* *}$ & $-.5(0.2)^{* * *}$ & $-.62(0.2)^{* * *}$ \\
\hline $\begin{array}{l}\text { Resource } \\
\text { potential }\end{array}$ & $.004(0.003)$ & $.01(0.0039$ & $-.001(0.002)$ & $.01(0.003)^{*}$ & $-.01(0.002)^{* * *}$ & $.004(0.002)^{* *}$ & $.0002(0.001)$ & $.003(0.002)^{* *}$ \\
\hline Corruption & $-.04(0.12)$ & $.06(0.13)$ & $.15(0.1)^{*}$ & $.14(0.11)$ & $.08(0.05)$ & $-.02(0.04)$ & $.01(0.03)$ & $-.01(0.04)$ \\
\hline Port & $-.14(0.2)$ & $.02(0.22)$ & $-.13(0.16)$ & $.29(0.2)$ & $.07(0.08)$ & $.32(0.07)^{* * *}$ & $.24(0.06)^{* * *}$ & $.34(0.08)^{* * *}$ \\
\hline Market size & $.02(0.02)$ & $.03(0.01)^{* *}$ & $.03(0.02)^{*}$ & $-.01(0.02)$ & $.26(0.03)^{* * *}$ & $.09(0.02)^{* * *}$ & $.16(0.02)^{* * *}$ & $.1(0.02)^{* * *}$ \\
\hline $\begin{array}{l}\text { Market } \\
\text { potential }\end{array}$ & $-.01(0.01)$ & $\begin{array}{l}.002(0.01) \\
\end{array}$ & $\begin{array}{l}.002(0.01) \\
\end{array}$ & $.01(0.01)$ & $-.003(0.01)$ & $\begin{array}{l}.01(0.01) \\
\end{array}$ & $-.001(0.005)$ & .001(0.01) \\
\hline $\begin{array}{l}\text { Investment } \\
\text { risk }\end{array}$ & $-.002(0.002)$ & $-.002(0.001)$ & $-.002(0.01)$ & $-.001(0.001)$ & $-.001(0.002)$ & $.001(0.001)$ & $.0004(0.001)$ & $.001(0.002)$ \\
\hline $\begin{array}{l}\text { Educational } \\
\text { level }\end{array}$ & $1.9(0.39)^{* * *}$ & $2.24(0.42)^{* * *}$ & $1.3(0.3)^{* * *}$ & $1.8(0.34)^{* * *}$ & $.81(0.17)^{* * *}$ & $1.3(0.17)^{* * *}$ & $1.1(0.14)^{* * * *}$ & $1.3(0.2)^{* * *}$ \\
\hline $\begin{array}{l}\text { Institutional } \\
\text { potential }\end{array}$ & $-.03(0.004)^{* * * *}$ & $-.02(0.003)^{* * *}$ & $-.02(0.003)^{* * *}$ & $-.01(0.003)^{* * *}$ & $-.03(0.002)^{* * *}$ & $-.02(0.002)^{* * *}$ & $-.02(0.001)^{* * *}$ & $-.02(0.002)^{* * * *}$ \\
\hline Roads & $.001(0.001)$ & $.002(0.001)^{* * * *}$ & $.0004(0.001)$ & $.0004(0.001)$ & $.003(0.0003)^{* * *}$ & $.004(0.0003)^{* * *}$ & $.004(0.0003)^{* * *}$ & $.004(0.0003)^{* * *}$ \\
\hline $\begin{array}{l}\text { Offshore } \\
\text { dummy }\end{array}$ & & & & $.48(0.2)^{* *}$ & & & & $.5(0.25)^{* *}$ \\
\hline $\begin{array}{l}\text { Time } \\
\text { dummies }\end{array}$ & Yes & Yes & Yes & Yes & Yes & Yes & Yes & Yes \\
\hline \multicolumn{9}{|c|}{ Interactions with offshore dummy } \\
\hline $\begin{array}{l}\text { Resource } \\
\text { potential*D }\end{array}$ & & & & $-.005(0.002)^{* * *}$ & & & & $-.01(0.002)^{* * *}$ \\
\hline Corruption*D & & & & $.001(0.05)$ & & & & $.05(0.06)$ \\
\hline Port*D & & & & $-.41(0.1)^{* * *}$ & & & & $-.24(0.11)^{* *}$ \\
\hline $\begin{array}{l}\text { Market } \\
\text { size*D }\end{array}$ & & & & $.05(0.02)^{* * *}$ & & & & $.17(0.03)^{* * *}$ \\
\hline $\begin{array}{l}\text { Market } \\
\text { potential*D }\end{array}$ & & & & $-.02(0.01)^{* *}$ & & & & $-.01(0.01)$ \\
\hline $\begin{array}{l}\text { Investment } \\
\text { risk*D }\end{array}$ & & & & -.0005608 & & & & $-.001(0.002)$ \\
\hline $\begin{array}{l}\text { Educational } \\
\text { level*D }\end{array}$ & & & & $-.23(0.2)$ & & & & $-.6(0.24)^{* *}$ \\
\hline $\begin{array}{l}\text { Institutional } \\
\text { potential*D }\end{array}$ & & & & $-.01(0.002)^{* * *}$ & & & & $-.01(0.003)^{* *}$ \\
\hline Roads*D & & & & $-.0003(0.0003)$ & & & & $-.001(0.001)$ \\
\hline $\begin{array}{l}\text { Log } \\
\text { likelihood } \\
\text { (for RENB) }\end{array}$ & -1788.7 & -2000.9 & -3967.4 & -3874.8 & & & & \\
\hline $\begin{array}{l}\text { Likelihood- } \\
\text { ratio test vs. } \\
\text { pooled (for } \\
\text { RENB) }\end{array}$ & $455^{* * *}$ & $383^{* * *}$ & $693^{* * *}$ & $731^{* * *}$ & & & & \\
\hline $\begin{array}{l}\text { Lnalpha (for } \\
\text { ZINB) }\end{array}$ & & & & & $-1.2^{* * * *}$ & $-1.3^{* * * *}$ & $-1^{* * *}$ & $-1.2^{* * * *}$ \\
\hline $\begin{array}{l}\text { Vuong test } \\
\text { (for ZINB) }\end{array}$ & & & & & $3.2^{* * *}$ & $3.6^{* * *}$ & $4.2^{* * *}$ & $4.3^{* * *}$ \\
\hline N.obs. & 988 & 988 & 1976 & 1976 & 988 & 988 & 1976 & 1976 \\
\hline
\end{tabular}

Note: 1$) *$ if $\mathrm{p}<0.10, * *$ if $\mathrm{p}<0.05$; *** if $\mathrm{p}<0.01 ; 2)$ standard errors in parentheses; 3 ) Lnalpha - the natural log of alpha (the dispersion parameter). If the dispersion parameter is zero, $\log$ (dispersion parameter $)=$-infinity. If this is true, then a Poisson model would be appropriate; 4) Vuong test compares ZINB model with an ordinary negative binomial regression model. A significant z-test indicates that ZINB is preferred.

From the results we can see that both round-trip and genuine foreign investors establish more firms in Russian regions with larger market size, higher institutional potential, higher educational background of population and better transport infrastructure (represented by railways and highways). 
For the resource potential and port variables we find opposite results for the two groups of investors. In particular, according to our findings, round-trip investors tend to establish more firms in Russian regions with higher resource potential, while their genuine foreign counterparts - with lower resource potential. This result might reflect restrictions for foreign investment in the Russian resource sector which are not applied to (or can be easily overcome by) round-trip investors who are Russians by origin.

We also find that while the presence of a sea port in a region stimulates genuine foreign investment into it, it is not an important factor of location decision of round-trip investors. We suggest that this indicates a higher orientation of round-trip investors towards the local market (both in inward and backward linkages) compared to their genuine foreign counterparts.

From the results for interaction terms with offshore dummy we further conclude that there are significant differences between location strategies of round-trip and genuine foreign investors. In particular we find that round-trip investors establish more firms than their genuine foreign counterparts in resource abundant Russian regions, regions with larger market size, regions with higher institutional potential, regions without sea ports and regions with lower educational background of population.

The result for regional resource potential variable indicates that round-trip investors win genuine foreign investors in competition for natural resources. This result is expected. Round-trip investors being Russians by origin have better knowledge and connections with local business networks and regional authorities. These business networks and regional authorities play a crucial role in gaining access to natural resources. Moreover round-trip investors might be themselves full or partial owners of Russian companies in resource-based industries (e.g. they utilize offshore schemes to hide export revenues from local taxes) and hence, round-trip investment is simply the reinvestment of their incomes into the same company and region (e.g. in case of using offshore tax evasion schemes in export operations).

The finding that round-trip investors establish more firms than their genuine foreign counterparts in Russian regions with larger market size indicates that round-trip investment is more oriented towards local markets compared to genuine foreign. Furthermore this might also indicate that genuine foreign investors tend to export goods produced in Russia rather than sell them at local market.

The finding that round-trip investors establish fewer firms than genuine foreigners in regions with sea ports also has a plausible explanation (which is quite related to the explanation for the interaction with 
market size variable). As sea port is a convenient mean for international transportation, this result enables us to suggest that genuine foreign investors more often than round-trip investors rely on imported intermediate goods and export the produced goods to home or third countries.

The result that round-trip investors establish more firms than genuine foreigners in Russian regions with lower educational potential indicates that genuine foreign investment is more qualified labour intensive than round-trip investment.

\subsubsection{Micro versus small, medium and large firms}

As has been shown in Section 2 (data description) around 50\% of firms in our dataset are micro firms according to the Russian classification of company`s size (with annual gross revenues less than 1.5 million Euros). In order to determine if foreign investors pursue different location strategies in Russia when establishing firms of different size we estimate the location model for subsamples of micro firms and bigger firms (small, medium and large altogether according to the Classification). The estimation results of equation (2) are presented in table 3. The estimation period ends in 2008 as there are only few firms established in the years 2009, 2010 and 2011 which reported annual gross revenues. 
Table 3 Location model: RENB and ZINB models results

Dependent variable is the number of firms established in a Russian region $n(1, \ldots, 76)$ in a year $t(1997, \ldots, 2008)$ by an investor $j$ (1,2: round-trip and genuine foreign)

\begin{tabular}{|c|c|c|c|c|c|c|c|c|}
\hline \multirow[t]{3}{*}{ Variable } & \multicolumn{4}{|l|}{ All countries } & \multicolumn{4}{|c|}{$\begin{array}{l}\text { Developing and transition countries are excluded from genuine foreign } \\
\text { group }\end{array}$} \\
\hline & \multicolumn{2}{|l|}{ Micro firms } & \multicolumn{2}{|c|}{ Small, medium and large firms } & \multicolumn{2}{|l|}{ Micro firms } & \multicolumn{2}{|c|}{ Small, medium and large firms } \\
\hline & RENB & ZINB & RENB & ZINB & RENB & ZINB & RENB & ZINB \\
\hline Intercept & $.13(0.45)$ & $-.66(0.34)^{*}$ & $.17(0.6)$ & $-1.9(0.3)^{* * *}$ & $-.02(0.6)$ & $-1.88(0.37)^{* * *}$ & $-.93(0.62)$ & $-3.1(0.4) * * *$ \\
\hline $\begin{array}{l}\text { Resource } \\
\text { potential }\end{array}$ & $-.001(0.004)$ & $-.0003(0.003)$ & $.002(0.004)$ & $.001(0.002)$ & $.01(0.01)$ & $.01(0.003)^{* * *}$ & $.01(0.004)$ & $.002(0.003)$ \\
\hline Corruption & $.09(0.11)$ & $-.15(0.08)^{* *}$ & $.23(0.11)^{* *}$ & $.16(0.07)^{* *}$ & $.07(0.13)$ & $.02(0.09)$ & $.42(0.12)^{* * * *}$ & $.32(0.1)^{* * *}$ \\
\hline Port & $-.2(0.19)$ & $.56(0.13)^{* * *}$ & $.35(0.19)^{*}$ & $.35(0.11)^{* * * *}$ & $.37(0.23)$ & $.58(0.14)^{* * * *}$ & $.3(0.21)$ & $.47(0.15)^{* * *}$ \\
\hline Market size & $-.04(0.04)$ & $.16(0.05)^{* * *}$ & $.05(0.02)^{* *}$ & $.15(0.03)^{* * *}$ & $-.004(0.03)$ & $.11(0.04)^{* * *}$ & $.05(0.03)$ & $.12(0.04)^{* * *}$ \\
\hline $\begin{array}{l}\text { Market } \\
\text { potential }\end{array}$ & $.03(0.02)^{*}$ & $-.01(0.02)$ & $.03(0.02)^{* *}$ & $.02(0.01)$ & $.03(0.02)^{*}$ & $.02(0.02)$ & $.03(0.02)$ & $.01(0.02)$ \\
\hline $\begin{array}{l}\text { Investment } \\
\text { risk }\end{array}$ & $-.004(0.003)$ & $.001(0.003)$ & $.0003(0.003)$ & $.002(0.002)$ & $-.01(0.003)^{*}$ & $-.01(0.003)^{*}$ & $-.0001(0.004)$ & $.002(0.003)$ \\
\hline $\begin{array}{l}\text { Educational } \\
\text { level }\end{array}$ & $.9(0.36)^{* *}$ & $.98(0.3)^{* * *}$ & $1.9(0.4)^{* * *}$ & $1.12(0.24)^{* * *}$ & $1.86(0.45)^{* * *}$ & $.83(0.32)^{* * *}$ & $1.9(0.44)^{* * *}$ & $1.2(0.32)^{* * *}$ \\
\hline $\begin{array}{l}\text { Institutional } \\
\text { potential }\end{array}$ & $-.02(0.004)^{* * *}$ & $-.004(0.003)$ & $-.03(0.004)^{* * *}$ & $-.03(0.003)^{* * *}$ & $-.03(0.01)^{* * *}$ & $-.03(0.004)^{* * *}$ & $-.04(0.01)^{* * *}$ & $-.03(0.004)^{* * *}$ \\
\hline Roads & $.002(0.001)^{* * *}$ & $.004(0.001)^{* * *}$ & $.004(0.001)^{* * *}$ & $.005(0.0004)^{* * *}$ & $.002(0.001)^{* *}$ & $.004(0.001)^{* * *}$ & $.004(0.001)^{* * *}$ & $.006(0.001)^{* * *}$ \\
\hline $\begin{array}{l}\text { Offshore } \\
\text { dummy }\end{array}$ & $-.31(0.38)$ & $-.62(0.44)$ & $1.6(0.34)^{* * *}$ & $1.4(0.4)^{* * *}$ & $.64(0.4)$ & $.73(0.43)^{*}$ & $2.8(0.43)^{* * *}$ & $2.8(0.44)^{* * *}$ \\
\hline $\begin{array}{l}\text { Time } \\
\text { dummies }\end{array}$ & Yes & Yes & Yes & Yes & Yes & Yes & Yes & Yes \\
\hline \multicolumn{9}{|c|}{ Interactions with offshore dummies } \\
\hline $\begin{array}{l}\text { Resource } \\
\text { potential*D }\end{array}$ & $-.002(0.003)$ & $-.002(0.004)$ & $-.003(0.003)$ & $-.004(0.003)$ & $-.01(0.003)^{* *}$ & $-.01(0.004)^{* * *}$ & $-.01(0.004)^{* *}$ & $-.006(0.004)^{*}$ \\
\hline Corruption*D & $.2(0.1)^{* *}$ & $.21(0.11)^{*}$ & $-.27(0.09)^{* * * *}$ & $-.18(0.1)^{*}$ & $.05(0.1)$ & $.07(0.12)$ & $-.48(0.1)^{* * *}$ & $-.34(0.12)^{* * *}$ \\
\hline Port*D & $-.4(0.17)^{* *}$ & $-.31(0.18)^{*}$ & $-.46(0.13)^{* * *}$ & $-.36(0.15)^{* *}$ & $-.72(0.15)^{* * *}$ & $-.48(0.19)^{* *}$ & $-.37(0.16)^{* *}$ & $-.46(0.18)^{* *}$ \\
\hline $\begin{array}{l}\text { Market } \\
\text { size*D }\end{array}$ & $.1(0.04)^{* *}$ & $.08(0.07)$ & $.05(0.02)^{* *}$ & $.09(0.04)^{* *}$ & $.03(0.03)$ & $.18(0.06)^{* * *}$ & $.07(0.03)^{* *}$ & $.12(0.05)^{* * *}$ \\
\hline $\begin{array}{l}\text { Market } \\
\text { potential*D }\end{array}$ & $-.02(0.02)$ & $-.004(0.02)$ & $-.01(0.01)$ & $-.002(0.02)$ & $-.06(0.02)^{* * *}$ & $-.04(0.02)^{*}$ & $-.001(0.02)$ & $.01(0.02)$ \\
\hline $\begin{array}{l}\text { Investment } \\
\text { risk*D }\end{array}$ & $.002(0.003)$ & $.001(0.0004)$ & $-.01(0.003)^{*}$ & $-.01(0.003)^{* *}$ & $.01(0.004)$ & $.01(0.003)$ & $-.01(0.004)^{*}$ & $-.01(0.004)^{*}$ \\
\hline $\begin{array}{l}\text { Educational } \\
\text { level*D }\end{array}$ & $-.61(0.35)^{*}$ & $-.42(0.42)$ & $-.1(0.3)$ & $-.23(0.33)$ & $-.27(0.35)$ & $-.66(0.41)$ & $-.08(0.36)$ & $-.31(0.4)$ \\
\hline $\begin{array}{l}\text { Institutional } \\
\text { potential*D }\end{array}$ & $-.01(0.004)^{* * *}$ & $-.02(0.004)^{* * *}$ & $.001(0.004)$ & $.002(0.004)$ & $.0003(0.01)$ & $.01(0.01)^{*}$ & $.01(0.01)^{*}$ & $.01(0.01)$ \\
\hline Roads*D & $.0003(0.001)$ & $.0001(0.001)$ & $\begin{array}{l}- \\
.002(0.001)^{* * *}\end{array}$ & $-.002(0.001)^{* * *}$ & $.001(0.001)^{* *}$ & $.001(0.001)$ & $\begin{array}{l}- \\
.002(0.001)^{* * *}\end{array}$ & $-003(0.001)^{* * *}$ \\
\hline $\begin{array}{l}\text { Log } \\
\text { likelihood }\end{array}$ & -2415.9 & -2435.4 & -1904.4 & -1904.4 & -1728.1 & & -1632.7 & \\
\hline $\begin{array}{l}\text { Likelihood- } \\
\text { ratio test vs. } \\
\text { pooled (for } \\
\text { RENB) }\end{array}$ & $280^{* * * *}$ & & $151^{* * * *}$ & $151^{* * *}$ & $205^{* * * *}$ & & $124^{* * *}$ & \\
\hline $\begin{array}{l}\text { Lnalpha (for } \\
\text { ZINB) }\end{array}$ & & $-0.39 * * *$ & & & & $-1.04 * * *$ & & \\
\hline $\begin{array}{l}\text { Vuong test } \\
\text { (for ZINB) }\end{array}$ & & $3.1^{* * *}$ & & & & $3.67^{* * *}$ & & $2.61 * * *$ \\
\hline N.obs. & 1824 & 1824 & 1824 & 1824 & 1824 & 1824 & 1824 & 1824 \\
\hline
\end{tabular}

Note: 1$) *$ if $\mathrm{p}<0.10, * *$ if $\mathrm{p}<0.05 ; * * *$ if $\mathrm{p}<0.01 ; 2)$ standard errors in parentheses; 3 ) Lnalpha - the natural log of alpha (the dispersion parameter). If the dispersion parameter is zero, $\log$ (dispersion parameter) $=$-infinity. If this is true, then a Poisson model would be appropriate; 4) Vuong test compares ZINB model with an ordinary negative binomial regression model. A significant z-test indicates that ZINB is preferred.

In general the results do not differ much from the baseline and between the subsamples. However, we have mixed results for the corruption variable. In particular for bigger firms (i.e. when micro firms are excluded) we find that genuine foreign investors establish more firms in less corrupt Russian regions compared to their round-trip counterparts. This result could be expected. But for micro firms we found an opposite and unexpected result that genuine foreign investors establish more firms in more corrupt Russian regions and furthermore they invest more into more corrupt Russian regions compared to round-trip investors. 
After checking the structure of firms in our data by country we found that many firms established by investors from developing and transition economies are micro firms. As a rule these countries are much more corrupt than developed ones. Investors from corrupt countries may be more equipped to cope with corruption (Cuervo-Cazurra, 2006), and, hence, they may have a competitive advantage over investors from non-corrupt countries when entering corrupt economies. In our earlier study using the same database as in this paper we also found that foreign investors from more corrupt countries tend to establish firms in more corrupt Russian regions (Ledyaeva et al. forthcoming). To account for this issue we estimate our model excluding from the genuine investors`group firms established by investors from developing and transition countries. The results are presented in the last two columns of Table 3. As we can see the unexpected result for corruption variable in the sample of micro firms disappears: the coefficients of the corruption variable and its interaction term with offshore dummy are not statistically significant anymore. Moreover, in the subsample of bigger firms the result that genuine foreign investors establish more firms in less corrupt Russian regions becomes stronger.

\subsubsection{Industrial patterns}

Next we estimate our location model for two sectors of the Russian economy, namely, manufacturing and combined financial and real estate sectors. We focus on these sectors because the first one largely reflects the real sector of the economy and its development is an important issue for Russian economy. The second one might be associated with corruption which is the main focus of this paper. The estimation results are presented in table 4. Here we use cross-sectional data as in panel data the number of zeros is extremely high and it is impossible to get reliable estimates even with zero-inflated models. For estimation purposes we utilize Poisson and negative binomial (NB) models. 
Table 4 Location model: Industrial patterns. Estimation results for cross-section data

Dependent variable is the number of firms established in a Russian region n $(1, \ldots, 76)$ in the period of 1997-2011 (as cumulative) by an investor $\mathrm{j}(1,2$ : round-trip and genuine foreign)

\begin{tabular}{|c|c|c|c|c|}
\hline \multirow[t]{3}{*}{ Variable } & \multicolumn{2}{|l|}{ Manufacturing } & \multicolumn{2}{|c|}{ Financial and real estate sectors } \\
\hline & Micro firms & Bigger firms & Micro firms & Bigger firms \\
\hline & NB & NB & NB & Poisson \\
\hline Intercept & $.7(0.53)$ & $.01(0.6)$ & $-.37(0.75)$ & $-3.2(1.03)^{* * *}$ \\
\hline Resource potential & $.01(0.01)$ & $.01(0.01)$ & $-.001(0.01)$ & $.001(0.01)$ \\
\hline Corruption & $.01(0.12)$ & $.4(0.14)^{* * *}$ & $.18(0.17)$ & $.6(0.23)^{* * *}$ \\
\hline Port & $.16(0.24)$ & $.4(0.26)$ & $.28(0.3)$ & $.9(0.4)^{* * *}$ \\
\hline Market size & $-.03(0.07)$ & $-.001(0.09)$ & $.2(0.09)^{* *}$ & $.35(0.09)^{* * *}$ \\
\hline Market potential & $.04(0.03)^{*}$ & $.04(0.03)$ & $.01(0.03)$ & $.02(0.06)$ \\
\hline Investment risk & $-.004(0.01)$ & $.003(0.01)$ & $.002(0.01)$ & $.02(0.01)$ \\
\hline Educational level & $1.14(0.5)^{* *}$ & $.37(0.57)$ & $1.5(0.65)^{* *}$ & $.68(0.71)$ \\
\hline Institutional potential & $-.03(0.01)^{* * *}$ & $-.05(0.01)^{* * *}$ & $-.02(0.01)^{* * *}$ & $-.03(0.01)^{* * *}$ \\
\hline Roads & $.004(0.001)^{* * *}$ & $.01(0.001)^{* * *}$ & $.004(0.001)^{* * *}$ & $.004(0.001)^{* * *}$ \\
\hline Offshore dummy & $-1.2(0.95)$ & $.8(0.9)$ & $1.6(1.03)$ & $4.13(1.2)^{* * *}$ \\
\hline \multicolumn{5}{|c|}{ Interaction termswith offshore dummy } \\
\hline Resource potential*D & $-.02(0.01)^{* *}$ & $-.01(0.01)$ & $.001(0.01)$ & $-.01(0.01)$ \\
\hline Corruption*D & $.32(0.22)$ & $-.37(0.21)^{*}$ & $.07(0.24)$ & $-.5(0.27)^{*}$ \\
\hline Port*D & $-.07(0.41)$ & $-.7(0.4)^{*}$ & $.08(0.4)$ & $-.7(0.4)^{*}$ \\
\hline Market size*D & $.28(0.12)^{* *}$ & $.12(0.13)$ & $.16(0.14)$ & $.06(0.11)$ \\
\hline Market potential*D & $-.03(0.04)$ & $-.02(0.04)$ & $-.01(0.05)$ & $.03(0.06)$ \\
\hline Investment risk*D & $-.003(0.01)$ & $.004(0.01)$ & $-.002(0.01)$ & $-.01(0.01)$ \\
\hline Educational level*D & $-.99(0.87)$ & $-.06(0.8)$ & $-1.8(0.87)^{* *}$ & $-.76(0.84)$ \\
\hline Institutional potential*D & $.02(0.01)^{*}$ & $.02(0.01)^{*}$ & $-.013(0.01)$ & $-.01(0.01)$ \\
\hline Roads*D & $-.0003(0.002)$ & $-.001(0.002)$ & $-.0003(0.002)$ & $-.001(0.002)$ \\
\hline Likelihood-ratio test of alpha $=0$ & $10.2^{* * *}$ & $26.9 * * *$ & $43.3 * * *$ & 0.00 \\
\hline Pseudo R2 & 0.24 & 0.23 & 0.27 & 0.4 \\
\hline N. obs. & 152 & 152 & 152 & 152 \\
\hline
\end{tabular}

\section{Results`discussion}

\section{Manufacturing sector}

First, as in estimations for the whole sample we find that in the subsample of bigger manufacturing firms genuine foreign investors invest more into less corrupt regions compared to round-trip investors.

Second, for the subsample of micro firms we find that round-trip investors tend to establish more firms in regions with higher resource potential compared to their genuine foreign counterparts. This indicates that round-trip investors invest more than genuine foreigners into resource-based manufacturing industries which further confirm that they have better access to Russian natural resources than genuine foreign investors.

The interaction term of market size and offshore dummy is also positive and statistically significant indicating that round-trip investors invest more into regions with larger market size compared to genuine foreign investors. This result indicates that manufacturing firms established by round-trip investors are more 
likely to sell their goods at local (Russian) market while genuine foreign investors have higher propensity to export produced products.

We also find evidence (albeit marginally statistically significant) that in the subsample of bigger firms round-trip investors establish fewer firms in the regions with sea port compared to genuine foreign investors. This result indicates that in manufacturing sector firms established by genuine foreign investors are more oriented towards import of intermediate goods and export of produced products.

Finally, we find that both round-trip and genuine foreign investors tend to invest into regions with higher institutional potential and higher density of automobile and railway roads.

\section{Financial and real estate sector}

First, for larger firms, the coefficient of the interaction term between offshore dummy and corruption variable is statistically significant and its sign indicates that round-trip investors establish more firms in more corrupt regions compared to genuine foreigners. And as this is widely accepted that financial and real estate activities are largely associated with corruption money laundering, this result might reflect the corruption money laundering hypothesis of round-trip investment in Russia.

Second, for the subsample of larger firms the interaction term between offshore dummy and port variable is statistically significant and its sign indicates that genuine foreign investors establish more firms in regions with sea port compared to round-trip investors. This indicates that financial activities of genuine foreign investors might be largely associated with export-import transport operations.

There is also evidence that in the subsample of micro firms genuine foreign investors establish more firms in regions with higher educational potential of population compared to round-trip investors. Preliminary we suggest that this result indicates that genuine foreigners tend to establish financial and real estate firms in regions with more developed service sector (which might be partly reflected by higher educational potential of population).

Finally we find that market size, institutional potential and transport infrastructure are important location factors for both genuine foreign and round-trip investment. 


\subsection{Fractional dependent variable model}

The estimation results of equation (3) for the whole sample and for manufacturing and combined financial and real estate sectors are presented in table 5.

Table 5 Fractional logit model results: pooled unbalanced panel data over the period of 2002-2011 for firms established in the period of 1997-2001

Dependent variable is the fraction of annual gross revenues earned by firms established by round-trip investors in total annual gross revenues of all established firms (i.e. round-trip and genuine foreign groups altogether) in a Russian region $n(1, \ldots, 76)$ in a year $t$ $(2002, \ldots, 2011)$

\begin{tabular}{|l|l|l|l|}
\hline Variable & Whole sample & Manufacturing & Financial and real estate sectors \\
\hline Intercept & $2.4(0.41)^{* * *}$ & $1.2(0.5)^{* *}$ & $3.02(0.74)^{* * *}$ \\
\hline Resource potential & $.001(0.003)$ & $.01(0.004)$ & $-.01(0.01)$ \\
\hline Corruption & $-.5(0.08)^{* * *}$ & $-.75(0.13)^{* * *}$ & $-.84(0.21)^{* * *}$ \\
\hline Port & $-.74(0.15)^{* * *}$ & $-.57(0.2)^{* * *}$ & $-1.4(0.3)^{* * *}$ \\
\hline Market size & $.05(0.04)$ & $-.06(0.04)$ & $.01(0.08)$ \\
\hline Market potential & $-.02(0.01)^{*}$ & $.001(0.02)$ & $-.06(0.03)^{*}$ \\
\hline Investment risk & $.01(0.003)^{*}$ & $.002(0.004)$ & $-.01(0.01)^{* *}$ \\
\hline Educational level & $-.56(0.32)^{*}$ & $.84(0.44)^{*}$ & $1.9(0.63)^{* * *}$ \\
\hline Institutional potential & $-.004(0.004)$ & $.003(0.01)$ & $-.01(0.01)$ \\
\hline Roads & $-.002(0.001)$ & -.001 & $.001(0.001)$ \\
\hline Time dummies & Yes & Yes & Yes \\
\hline Log pseudolikelihood & -345.1 & -313 & -220.6 \\
\hline Pearson & 328.6 & 366 & 315.7 \\
\hline N. obs & 628 & 535 & 397 \\
\hline Note: 1$) *$ if p $<0.10, * *$ if $\mathrm{p}<0.05 ; * *$ if p $<0.01 ; 2)$ standard errors in parentheses. & \\
\hline
\end{tabular}

First, the share of round-trip activities is higher in corrupt Russian regions. This result is highly statistically significant in the whole sample and in both industrial subsamples. The result has been expected and in general confirms that 1) round-trip investors are better equipped to cope with corruption than their genuine foreign counterparts and 2) round-trip investment might be an important channel for corruption money laundering in Russia.

Second, we find that the share of round-trip investment is lower in regions with ports. A similar result has been found in the location model. Hence, our conclusion that round-trip investors are more oriented towards local (Russian) market than genuine foreign investors is reinforced.

Fourth, the results for educational background of population are mixed. First, in manufacturing and combined financial and real estate sector the fraction of round-trip investment is higher in regions with higher educational background of population. We argue that though the result is the same for these two 
sectors, the explanations might be different. In particular, while in manufacturing industry it can be largely explained by the need of local qualified personnel, in combined financial and real estate sector, educational background of population might reflect a better development of the service sector in general. However, in the whole sample we find that the share of round-trip activities is higher in regions with lower educational background of population. In our preliminary estimations we found that this result for the whole sample largely reflects the result for trade and repair sector. In general it might point to the higher technological level of genuine foreign investment compared to round-trip investment in this sector.

\section{CONCLUSIONS}

This paper sheds light on a virtually unexplored phenomenon: round-trip investment from Russia to offshore financial centers and back to Russia. In particular we empirically study the link between corruption and round-trip investment. Our empirical test is based on the firm-level data on foreign-owned firms in Russia obtained from Rosstat. Our main results can be summarized as follows.

First, we find quite robust evidence that round-trip investors tend to invest into more corrupt Russian regions than genuine foreign investors. This result gives support for the proposition of laundering the proceeds of corruption via round-trip investment (in particular it's high significance for the combined financial and real estate sector). It further indicates that round-trip investors may indeed be better equipped to cope with institutional deficiencies, e.g., corruption (in particular, the result`s significance in manufacturing sector).

Second, we find evidence that round-trip investors invest more into regions with higher resource potential compared to their genuine foreign counterparts. This finding indicates that round-trip investors are better able to exploit the business opportunities provided by the Russian natural resources than genuine foreign investors. This often requires allying with authorities, which is obviously easier for round-trip investors than for genuinely foreign investors. Furthermore, round-trip investors might be themselves the representatives of the authorities who already have access to resources.

Finally, our results enable us to suggest that round-trip investors favor the development of the Dutch disease in Russia. In particular they are very highly concentrated in the service sector (real estate and financial activities, in particular), seem to aim at exploiting natural resources in Russia, tend to establish 
manufacturing firms in resource-based industries and support the development of corruption in Russia by investing into corrupt Russian regions. On the contrary, genuine foreign investments seem to work against the Dutch disease as they are more concentrated in manufacturing industries and regions with higher educational potential of population but are not tied to resource abundant and corrupt Russian regions.

\section{Appendix 1}

Descriptive statistics and correlation matrix of the variables in the baseline location model

\begin{tabular}{|l|l|l|l|l|l|l|l|l|l|l|l|l|l|l|}
\hline & Mean & $\begin{array}{l}\text { Std. } \\
\text { Dev. }\end{array}$ & Min & Max & DV & $\begin{array}{l}\text { ResPo } \\
\mathrm{t}\end{array}$ & Corr & Port & $\begin{array}{l}\text { Msiz } \\
\mathrm{e}\end{array}$ & $\begin{array}{l}\text { Mpot } \\
\text { InvRis } \\
\mathrm{k}\end{array}$ & $\begin{array}{l}\text { EDU } \\
\text { InstPot }\end{array}$ & $\begin{array}{l}\text { Road } \\
\mathrm{s}\end{array}$ \\
\hline DV & 6,50 & 29,64 & 0,00 & 484,00 & 1,00 & & & & & & & & & \\
\hline Resource potential & 43,10 & 23,89 & 1,00 & 89,00 & 0,19 & 1,00 & & & & & & & & \\
\hline Corruption & 2,76 & 0,70 & 1,00 & 5,00 & $-0,10$ & 0,09 & 1,00 & & & & & & & \\
\hline Port & 0,21 & 0,41 & 0,00 & 1,00 & $-0,01$ & $-0,31$ & $-0,19$ & 1,00 & & & & & & \\
\hline Market size & 0,01 & 1,49 & $-0,94$ & 16,34 & 0,84 & 0,17 & $-0,18$ & 0,00 & 1,00 & & & & & \\
\hline Market potential & 1,66 & 4,59 & $-6,96$ & 23,15 & $-0,13$ & 0,33 & 0,17 & $-0,21$ & $-0,20$ & 1,00 & & & & \\
\hline Investment risk & 40,37 & 23,74 & 1,00 & 88,00 & $-0,19$ & $-0,29$ & $-0,15$ & 0,12 & $-0,25$ & $-0,10$ & 1,00 & & & \\
\hline Educational level & 0,57 & 0,22 & $-0,21$ & 1,31 & 0,33 & $-0,12$ & 0,08 & 0,33 & 0,40 & $-0,14$ & $-0,17$ & 1,00 & & \\
\hline Institutional potential & 39,57 & 22,70 & 1,00 & 82,00 & $-0,27$ & 0,17 & 0,05 & $-0,13$ & $-0,48$ & 0,14 & 0,40 & $-0,33$ & 1,00 & \\
\hline Roads & 142,60 & 103,19 & 1,41 & 606,50 & 0,44 & 0,54 & $-0,05$ & $-0,20$ & 0,44 & 0,20 & $-0,47$ & 0,05 & $-0,26$ & 1,00 \\
\hline
\end{tabular}




\section{References}

Basile, R., 2004. Acquisition Versus Greenfield Investment: the Location of Foreign Manufacturers in Italy. Regional Science and Urban Economics 34, 3-25.

Basu, S., Phelps, C., Kotha, S., 2011. Towards understanding who makes corporate venture capital investments and why. Journal of Business Venturing 26, 153-171.

Blonigen, B. A., Davies, R. B., Waddell, G. R., Naughton, H. T., 2007. FDI in space: Spatial autoregressive relationships in foreign direct investment. European Economic Review 51(5), 1303-1325.

Carr, D.L., Markusen, J.R., Maskus, K.E., 2001. "Estimating the Knowledge-Capital Model of the Multinational Enterprise," American Economic Review, American Economic Association, vol. 91(3), pages 693-708.

Cuervo-Cazurra, A., 2006. Who cares about corruption? Journal of International Business Studies 37(6), 807-822.

Dolmatova, V.Yu. (2010). Classification of Russian companies (Klassifikatsiya rossijskih predpriyatij), Audit and financial analysis (Audit i finansovyj analiz), 2.

Greene, W. H., 2000. Econometric analysis. Upper Saddle River, third edition, NJ: Prentice-Hall.

Hausman, J. A., Hall, B. H., Griliches, Z., 1984. Econometric Models for Count Data with an Application to the Patents-R\&D Relationship. Econometrica 52(4), 909-38.

Hedge, D., Hicks, D., 2008. The maturation of global corporate R\&D: Evidence from the activity of U.S. foreign subsidiaries. Research Policy 37, 390-406.

Iwasaki, I., Suganuma K., 2005. Regional Distribution of Foreign Direct Investment in Russia. PostCommunist Economies 17: 2, 153-72.

Kalotay, K., 2005. Outward Foreign Direct Investment from Russia in a Global Context. Journal of EastWest Business, 11: 3/4, 9-33.

Lambert, D., 1992. Zero-Inflated Poisson Regression, with an Application to Defects in Manufacturing. Technometrics 34 (1), 1-14. 
Ledyaeva, S., 2009. Spatial Econometric Analysis of Foreign Direct Investment Determinants in Russian Regions. The World Economy, 32 (4), 643-666.

Ledyaeva S., Karhunen P. \& Kosonen R. (2013). Corruption, democracy, and the location decisions of foreign investors in Russian regions: The role of home countries characteristics, forthcoming in European Journal of Political Economy

Papke, L.E. \& J. M. Wooldridge. 1996. Econometric Methods for Fractional Response Variables with an Application to 401(k) Plan Participation Rates. Journal of Applied Econometrics 11(6), 619-632.

Papke, Leslie E. \& Wooldridge, Jeffrey M., 2008. "Panel data methods for fractional response variables with an application to test pass rates," Journal of Econometrics, 145(1-2), 121-133.

Perez M.F., Brada J.C., Drabek Z. 2012. Illicit money flows as motives for FDI. Journal of comparative economics 40(1), 108-126.

Rose and Spiegel, 2007. Offshore financial centers: parasites or symbionts? Economic journal, 117 (523), 1310-1335.

Rossidou-Papakyriacou E., 1999. International Co-operation in the Fight against Corruption from the point of view of an Offshore Centre”, paper presented at the $4^{\text {th }}$ European Conference of Specialised Services in the Fight against Corruption, Limassol (Cyprus), 20-22 October. 